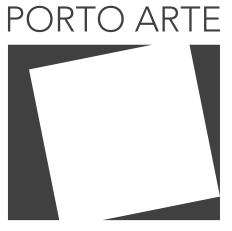

Revista de Artes Visuais

V.25 n. 44 $\mathrm{Jul} / \mathrm{dez} 2020$ e-ISSN: 2179-8001

\title{
Lorenzo Fernândez: considerações sobre sua contribuição à música brasileira da primeira metade do século $\mathbf{X X}$
}

Lorenzo Fernândez: considerations about his contribuction to the brazilian music of the firs halph of twenty century XX

\section{José D'Assunção Barros}

ORCID: 0000-0002-3974-0263

Universidade Federal Rural do Rio de Janeiro, Brasi

\section{Resumo}

Este artigo propõe a apresentar e discutir a obra musical de Lorenzo Fernândez, considerando-a do ponto de vista de sua possível divisão em fases e orientando a análise em torno de aspectos que incluem (1) o modelo de utilização do folclore musical empregado em suas obras nacionalistas; (2) a especificidade formal dos padrões composicionais de Lorenzo Fernândez e sua utilização de formas musicais diversas; (3) a variedade de gêneros musicais percorrida pela atividade composicional deste autor.

Palavras-chave Lorenzo Fernândez. Nacionalismo Musical. Música de Concerto.

\section{Abstract}

This article aims to discuss the musical work of Lorenzo Fenândez, examining it on the perspective on the possibility of considering this work in different phases and directing the analysis around aspects that include (1) the pattern of utilization of the musical folklore used in his nationalistic works, (2) the formal specificity of the compositional models of Lorenzo Fenândez and their utilization in various musical forms, (3) the variety of musical genders experienced by the compositional activity of the author.

Keywords

Lorenzo Fernândez. Musical Nationalism. Concert Music. 


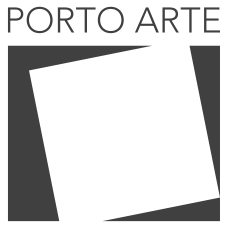

Revista de Artes Visuais

\section{Lorenzo Fernândez: delimitação de um perfil composicional}

Lorenzo Fernândez foi um dos compositores brasileiros mais significativos da música de concerto brasileira da primeira metade do século $\mathrm{XX}$, apresentando especial destaque na constelação de músicos brasileiros ligados à corrente nacionalista. Neste artigo, examinaremos a sua obra procurando classificá-la nos vários gêneros musicais que a constituem, e abordá-las no âmbito de possíveis fases que podem ser vistas como diferentes períodos de sua atividade composicional ${ }^{1}$. De igual maneira, perceberemos que é fundamental a relação deste compositor com o nacionalismo musical - que pode ser compreendido como o princípio assumido por um compositor de utilizar, em suas obras, um espírito francamente impregnado do folclore e da música popular de seu país². Neste aspecto em particular, pode-se dizer que Lorenzo Fernândez tendeu gradualmente à utilização do 'folclore imaginário' - um conceito que delimitaremos melhor mais adiante - mais do que à assimilação de materiais folclóricos colhidos diretamente, que aparece cada vez menos à medida que nos afastamos das suas primeiras obras nacionalistas. Por fim, será importante abordar os aspectos mais propriamente composicionais de sua obra, considerando-se que, neste âmbito, Lorenzo Fernândez situou-se em um ponto de cuidadoso equilíbrio entre o experimentalismo de índole modernista e a linguagem musical mais direta, capaz de fascinar também o ouvinte comum. Em outras palavras, afastou-se simultaneamente da banalidade e do hermetismo sonoro, conseguindo assegurar a difícil arte de ser ao mesmo tempo agradável e interessante.

\footnotetext{
1- As fontes centrais para as reflexões desenvolvidas neste trabalho são as próprias composições de Lorenzo Fernândez, relativas aos mais diversos gêneros musicais. Atentamos também para a importância do catálogo geral da obra do compositor, publicado em 1992 (CORREA, Sergio Nepomuceno. Lorenzo Fernández: catálogo geral. Rio de Janeiro: Rio Arte, 1992)

2- Essa é uma definição operacional de 'nacionalismo musical', que a partir de um conceito mínimo pode se sintonizar com as discussões estéticas que começam a ser desenvolvidas no Brasil e na Europa desde os anos 1930 e que se estendem pelas décadas seguintes, até chegar aos dias de hoje. Por outro lado, para além desta conceituação mínima há uma história envolvida neste debate: ela diz respeito a nuances que consideram se a principal fonte para o nacionalismo deveria ser a música folclórica rural, as raízes étnicas ou a música urbana - ou todas estas matrizes - e também à questão que discute se o nacionalismo precisa ser confrontado antagonicamente em relação a propostas universalistas ou à música de inspiração européia. Na Europa, já nas primeiras décadas do século XX compositores modernos como Béla Bartók procuram articular um nacionalismo musical moderno à pesquisa sobre o folclore de cada país, e este mesmo compositor foi autor de importantes Escritos sobre a Música Popular (1979). No Brasil, um texto pioneiro que radicaliza a oposição entre uma música de concerto nacionalista e uma música brasileira que apenas segue os ditames estéticos europeus, depreciando particularmente esta última proposta, foi o Ensaio sobre a Música Brasileira, de Mário de Andrade (1928). Esta obra tornou-se um guia estético e ético para muitos compositores da primeira metade do século XX - conforme argumenta Arnaldo Contier em sua tese de livre docência (1988) - e suas propostas de antagonismo em relação à música moderna não-nacionalista seriam depois radicalizadas pelas célebres Cartas Abertas de Camargo Guarnieri, publicadas nos jornais de 1950. Estas, e as réplicas de Koellreutter, acham-se integralmente reproduzidas no livro de Carlos Kater sobre o Música Viva e Koellreutter (2001), e também no livro de José Maria Neves sobre a Música Contemporânea Brasileira (1981).. No entanto, nacionalismo e assimilação da música moderna européia podem conviver perfeitamente, e inclusive serem incorporados na mesma prática musical, como demonstrou Villa-Lobos em diversas de suas composições. Uma discussão sobre o debate acerca do nacionalismo musical no Brasil, a partir da obra de três compositores do período (Guarnieri, Mignone e Guerra Peixe), pode ser encontrada em dois textos de André Egg (2004 e 2007). Uma análise da apropriação política do nacionalismo musical na década de 1920 pode ser encontrada em Wisnik (1977). Já a presença da nacionalismo como uma corrente importante da produção musical europeia das décadas de 1930 e 1940 é bem discutida por Griffiths (1998, p.49-61)
} 


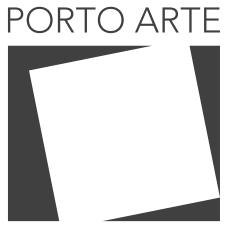

Revista de Artes Visuais

$\vee 25 n .44$

$\mathrm{Jul} / \mathrm{dez} 2020$ e-ISSN: 2179-8001

Acima de tudo isto, o exame das obras de Lorenzo Fernândez poderá nos mostrar que este compositor dedicou uma atenção bastante especial à forma musical, sempre concebida de modo neoclássico. Neste ponto difere de Villa-Lobos, para quem a forma quase sempre vinha em segundo plano em relação ao conteúdo musical e à espontaneidade da inspiração, mas também de Camargo Guarnieri - que em algumas composições deixa entrever uma concepção em que o planejamento rigoroso da forma precede de maneira absoluta toda a música que virá depois. As composições de Lorenzo Fernândez, ao contrário de um e de outro, revelam habitualmente aquele entretecer mútuo de conteúdo e forma que veremos na Sonata Breve ou nas Suítes Brasileiras - obras tão diferentes do ponto de vista da linguagem musical, no entanto tão irmanadas pelo cuidado estrutural ${ }^{3}$. Estas e outras obras típicas de Lorenzo Fernândez não parecem nem correr o risco de eliminar a forma sob o peso de uma esmagadora inspiração, nem de se escravizar à forma como se esta fosse um valor soberano. 0 equilíbrio é a sua palavra de ordem (esta característica, aliás, traspassa todas as fases da obra musical de Lorenzo Fernândez, não se atendo apenas ao período mais acentuadamente nacionalista).

De um modo geral, são estes os vetores que formatam o nacionalismo musical de Lorenzo Fernândez - que se mostra a um só tempo distinto do audacioso experimentalismo do Villa-Lobos da década de 20, do tratamento mais rapsódico de Francisco Mignone, e da austeridade de Camargo Guarnieri. Estes são aspectos gerais que predominam na obra do compositor carioca, o que não quer dizer que se tenha aqui uma obra monolítica. É assim que, para além da identificação destes parâmetros fundamentais, os musicólogos e analistas não têm tido maior dificuldade em dividir a obra do compositor em fases mais ou menos bem definidas. Partindo de uma primeira fase levemente tocada pelo deslumbramento impressionista do período pré-modernista, a vida e obra de Lorenzo Fernândez parecem modular a uma fase mais radicalmente marcada pelo entusiasmo nacionalista, e daí parecem tender mais tarde a um padrão mais universalista de composição e até de conceber o mundo.

\section{Lorenzo Fernândez e os Modos de trabalhar o folclore}

Antes de refletirmos sobre a relação fundamental de Lorenzo Fernândez com o folclore nacional, convém fazermos uma indagação mais ampla com relação a todos os compositores brasileiros que têm no Nacionalismo Musical uma marca fundamental. Como o compositor brasileiro lida com o folclore? Será esta a indagação orientadora, a partir daqui. Com o intuito de estabelecer uma tipologia das estratégias de composição, partiremos de dois sentidos ou atitudes básicas em torno da expressão

\footnotetext{
3- Comentários sobre as habilidades técnicas e inventividade musical de Lorenzo Fernández ajustadas a uma forma precisa, foram proferidos por Mário de Andrade ainda em 1926 em uma crônica para o Diário de São Paulo (a mesma foi publicada, mais tarde, (incluída em CASTAGNA, 1993). O próprio Heitor Villa-Lobos em um artigo de 1946 para o Boletim Latino Americano de Música, dedicado a alguns comentários sobre Lorenzo Fernández, ressalta a diferença entre o maior formalismo de Lorenzo Fernández e o seu próprio modo de compor (VILLA-LOBOS, 1946. p.591). No mesmo número deste periódico, Lorenzo Fernández também dedica seus próprios comentários ao padrão composicional de Villa-Lobos (LORENZO FERNÂNDES, 1946. p.284)
} 


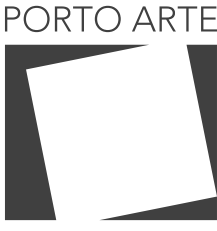

Revista de Artes Visuais

$\vee 25 n .44$

Jul/dez 2020 e-ISSN: 2179-8001

"Nacionalismo Musical". Há em primeiro lugar os compositores que se apropriam de material folclórico preexistente em seu país ou localidade (ou até mesmo de localidades que não a sua) e o integram menos ou mais literalmente em sua obra, transcrevendo-o, assimilando-o, elaborando-o, deformando-o, harmonizando melodias que já fazem parte do cancioneiro folclórico ou popular. Toma-se neste caso melodias que já existem na cultura de um povo, instrumentos característicos que são deslocados do espaço folclórico ou popular para o ambiente erudito, temas musicais específicos que são reconstituídos criteriosamente.

Em alguns casos, surge aqui a figura do 'músico-pesquisador', que no século $X X$ passa a dispor de métodos científicos e de recursos tecnológicos apurados para a recoIha do material folclórico e popular. Luciano Gallet (1893-1931)4, Ernani Braga (18981948) e muitos outros foram verdadeiros pioneiros na pesquisa musical brasileira já na primeira década do século XX - à imagem do que se fazia na Europa e nos demais países americanos do mesmo período. São exemplos deste novo tipo de músico que enfrenta de maneira moderna a matéria-prima folclórica ou popular. Sua postura com relação à recolha do folclore pátrio já não é ingênua como a do compositor nacionalista do período romântico: o músico-pesquisador deixa de ser um coletor casual de elementos folclóricos, que apenas flutuam na superfície, para se tornar um estudioso que desce às profundezas da alma nacional, que extrai com método verdadeiras joias do folclore e da cultura popular. Não raro ele empreende viagens de estudo para entrar em contato direto com as manifestações folclóricas, embora também não seja incomum flagrá-lo investigando arquivos.

De qualquer modo, nem todos os que trabalham dentro da perspectiva de aproveitar materiais folclóricos já preexistentes serão necessariamente músicos-pesquisadores, uma vez que para isto se exige uma espécie de preparação ou talento especial. É preciso fôlego para "por o pé na estrada" - como fizeram Villa-Lobos no Brasil ou Béla Bartók na Hungria - e paciência e meticulosidade para gastar dias inteiros nos arquivos sonoros e documentais, como fez Luciano Gallet ao se dedicar à escuta sistemática dos arquivos sonoros indígenas trazidos pela Missão Rondon para o Museu Nacional ${ }^{5}$.

Mas há outras maneiras de lidar com o folclore que não a de coletar ou refinar os seus produtos diretos. Uma segunda atitude classificável como "nacionalismo musical" pode ser encontrada naqueles compositores que são chamados de "nacionalistas" não porque transcreveram ou exploraram materiais folclóricos preexistentes, mas porque, embora criando materiais melódicos e musicais inteiramente novos, incorporaram o espírito de um povo. Mais do que os temas musicais, a sua alma é que se apresenta

\footnotetext{
4- A faceta de ensaísta e pesquisador do folclore, em Luciano Gallet, aparece em seus Estudos de Folclore (1934).

5- Villa-Lobos dedicou três anos de sua vida a uma viagem através do Brasil, de norte a sul, embora alguns autores chamem atenção para o fato de que foi muito mais uma viagem de peregrinação para conhecer a diversidade cultural de sua terra do que a viagem de um pesquisador sistemático, que anota e grava com método científico a música folclórica com que se depara. Béla Bartók, já inegavelmente o maior músico-pesquisador da história da música ocidental, empreendeu sucessivas viagens de estudos: em 1906 a viagem pelo interior da Hungria; entre 1909 e 1912 viagens para a coleta de canções populares na Romênia Bulgária, Ucrânia; em 1913 uma viagem através do sul da Argélia; em 1936 uma viagem à Turquia. A variedade de povos que estudou eleva Bartók, além de músico nacionalista da Hungria, a uma posição invejável de verdadeiro folclorista planetário. Obviamente que, para o caso de Villa-Lobos e outros compositores brasileiros, deve ser lembrada ainda a dimensão continental do Brasil e sua enorme variedade interna.
} 


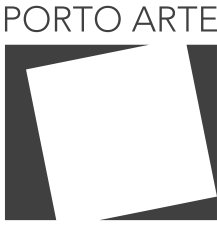

Revista de Artes Visuais

$\vee 25 n .44$

$\mathrm{Jul} / \mathrm{dez} 2020$ e-ISSN: 2179-8001

como nacionalista. Ainda no século XIX, o compositor polonês Frederick Chopin (18101849) teria sido um nacionalista deste tipo. As suas polonaises e mazurkas não foram criadas a partir de melodias que já existiam literalmente no folclore polonês. Foram, isto sim, extremamente originais, mas apesar disto reveladoras de um autêntico espírito polonês (CANDÉ, 1994, p.58). O musicólogo Serguei Moreux (1954) exemplifica esta linha de ação com o compositor húngaro Béla Bartók e a define através da expressão "nacionalismo imaginário", mostrando que nela o compositor assimila conscientemente o espírito nacional embora dele dispondo livremente. No Brasil do século XX, esta segunda atitude nacionalista também está fartamente representada. 0 compositor Waldemar Henrique (1905-1995), por exemplo, costumava compor à maneira do folclore da Amazônia, mas sempre produzindo temas próprios. Tratava-se, portanto, de captar o espírito de sua região, e não de partir de materiais já existentes. Para já citar o caso de Lorenzo Fernândez como ilustração acerca do que seria a imaginação musical aplicada à possibilidade de construção de um "folclore imaginário", podemos reproduzir os comentários de Mário de Andrade em relação à Sonatina, de Lorenzo Fernândez:

\footnotetext{
"Os três tempos, magnificamente bem proporcionados, são uma síntese da estética nacionalista de Lorenzo Fernández, que, desde o Trio, já aplicava o elemento folclórico apenas como princípio temático, reduzindo-o muitas vezes a um mínimo de célula condutora da invenção. Realmente, ninguém mais inteligentemente, nem mais habilmente que ele já soube aproveitar as constâncias rítmico-melódicas, as células caracterizantes da nossa produção popular e tirar delas as possibilidades duma criação livre, individualista, mas incontrastavelmente nacional" (ANDRADE, 1934, p.181).
}

O folclore imaginário poderia ser ilustrado pelo comentário acima, embora Mário de Andrade não tenha utilizado esta expressão. Ele reside nesta capacidade de o compositor partir de algo - conservando essencialmente a natureza mais íntima deste material de partida, que pode ser um ritmo, uma célula, um caráter - e a partir daí produzir uma composição inteiramente criativa. 0 compositor, capaz de lidar com a técnica apropriada e dotado do espírito que o sintoniza com o folclore cuja natureza apreendeu, seria capaz de construir uma inteiramente nova - a qual, não sendo folclore, inspiraria em quem a ouvisse a sensação indescritível de que seria folclore, embora refinado e inteiramente de lavra original.

Além dos já citados grupos que trabalham respectivamente com o 'folclore preexistente' e com uma 'imaginação folclórica' que termina por construir um criativo "folclore imaginário", existem por fim os compositores que transitam com igual liberdade entre uma prática e outra - entre a pesquisa e apropriação de temas folclóricos e a criação inédita dentro de um espírito nacional. Villa-Lobos (1887-1959) é para este caso o exemplo mais célebre no Brasil. Na Europa, o modelo maior foi reconhecidamente Béla Bartók (1881-1945) - compositor que de um lado lançou as bases científicas para a 


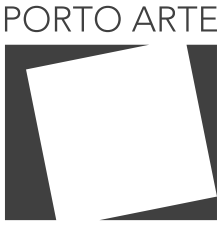

Revista de Artes Visuais $\vee 25 n .44$ Jul/dez 2020 e-ISSN: 2179-8001

pesquisa musicológica e as aplicou na recolha de milhares de melodias folclóricas de vários países, e que, de outro lado, produziu algumas das obras mais criativas do século XX, não propriamente transportando aquelas melodias para a sua obra, mas sim assimilando os seus espíritos nacionais dentro da criação de uma obra inédita.

Voltando ao compositor que presentemente analisamos, podemos dizer que Lorenzo Fernândez, tal como Villa-Lobos, utilizou ao longo de sua carreira composicional os dois procedimentos. Pode-se perceber uma tendência, por outro lado, à medida que sua trajetória musical avança no tempo. Lorenzo Fernândez tendeu cada vez mais à elaboração de um folclore imaginário, mais do que à assimilação de materiais folclóricos colhidos diretamente. Um exame das suas diversas fases composicionais poderá mostrar isto.

\section{As fases composicionais de Lorenzo Fernândez}

Podemos situar entre 1918 e 1922 uma primeira fase em que Lorenzo Fernândez está em busca de seu estilo e recebe alguma influência do Impressionismo Francês. Conforme vimos, isto também havia acontecido com Villa-Lobos pela mesma época, e pode-se aventar que o marco de 1922, que faz a passagem de uma fase a outra, também esteja por conta da poderosa repercussão da Semana de Arte Moderna. Obras muito características deste primeiro período - oscilante entre o Neo-Romantismo e o Impressionismo - são a Miragem (1919), no campo instrumental, e A Saudade, no campo vocal.

Entre 1922 e 1938, pode-se dizer que a música de Lorenzo Fernândez conhece uma fase mais característica de aproveitamento sistemático do folclore, e ele finalmente sintoniza aquele estilo pelo qual será sempre lembrado. Este período é o que contempla algumas das obras mais divulgadas: no campo instrumental, a Valsa Suburbana e as Suítes Brasileiras; no campo vocal canções de sabor bem brasileiro como a Toada prá Você ou ainda a Canção Sertaneja; no campo orquestral obras como o Reisado do Pastoreio.

Entre 1938 e 1948, por fim, Lorenzo Fernândez entra na sua fase mais aberta ao universalismo, explorando muita politonalidade e polirritmia como ocorre com a sua Sonata Breve. Boa parte deste período insere-se nos últimos anos do Estado Novo. Já havíamos visto que foi também a partir da década de 1940 que Villa-Lobos havia derivado para uma terceira fase em que vai abandonando o nacionalismo populista e neoclássico da sua "fase bachiana" para atingir na sua "fase terminal" uma posição mais eclética que alterna nacionalismo e universalismo, às vezes chegando a obras que voltam a ser tão experimentalistas como as que haviam sido concebidas sob a égide do nacionalismo modernista da "fase chorona".

Pode-se aventar a hipótese de que a coincidência da fase eclética de Villa-Lobos com a fase mais eclética e universalista de Lorenzo Fernândez seria um índice da maior abertura a novas alternativas culturais que vai sendo ampliada a partir da década de 1940. É só após 1948 que será reeditado o rigor polêmico das teorias da "brasilidade autêntica" contra os compositores e as práticas que estavam fora da órbita do Nacio- 


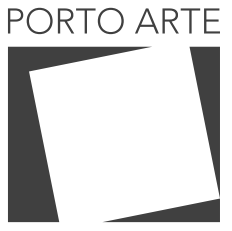

Revista de Artes Visuais

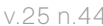

Jul/dez 2020 e-ISSN: 2179-8001

nalismo Musical. Mas então Lorenzo Fernândez já havia partido, e Villa-Lobos já era independente demais para se ater a dogmatismos estagnadores. Um e outro não precisariam tomar nenhuma posição diante da ruidosa querela das "Cartas Abertas" iniciada por Camargo Guarnieri.

\section{As duas primeiras fases: entre o Impressionismo e o Nacionalismo}

Identificados os grandes períodos, examinemos mais de perto as obras que os sustentam. Começaremos pelo ano de 1922 - data-base da dupla opção modernista e nacionalista - já que antes disto não existem tantas obras significativas no repertório produzido por Lorenzo Fernândez. Aqui, ainda aparecem as últimas obras que, do ponto de vista temático, poderiam ser associadas à primeira fase. Mas por outro lado estas mesmas obras já anunciam claramente a guinada modernista: a harmonia irá se expandir mais audaciosamente, deixando para trás o neo-romantismo tradicional; a forma passará a expressar uma importância mais central. Vão se tornar cada vez mais excepcionais as peças pianísticas que ainda são assinaladas por aquele neo-romantismo descritivo com cores levemente impressionistas - embora isto ainda ocorra, por exemplo, nas Historietas Maravilhosas para piano (1922), que retratam em pequenos episódios musicais alguns dos mais conhecidos contos de fadas ("Branca de Neve", "Gata Borralheira", "Pequeno Polegar", "Chapeuzinho Vermelho" e outros) 6 .

A exploração de temática infantil em pequenas peças descritivas para piano insere-se, aliás, em uma rede que já havia sido inaugurada por Villa-Lobos com a sua primeira série da Prole do Bebê (1919). Tanto Villa-Lobos como Lorenzo Fernândez eram fascinados por este gênero, e continuariam produzindo novas composições de temática infantil'. 0 gênero das 'suítes infantis para piano', diga-se de passagem, já havia sido inaugurado na música ocidental pelas Cenas Infantis do compositor alemão Robert Schumann (1838), e é muito importante se ter em vista que estas séries de temáticas infantis não são necessariamente de execução musical fácil (ou seja, nem sempre são para serem tocadas por crianças). Algumas das peças das Proles do Bebê de Heitor Villa-Lobos $(1918,1922,1926)$ requerem uma técnica bastante acurada.

Voltemos à trajetória nacionalista de Lorenzo Fernândez. Um sinal importante será dado pela canção intitulada Mãos frias (1922), que passa por ser uma de suas primeiras opções mais conscientes pelo Nacionalismo Musical. Isto não impede que, neste mesmo ano de 1922, o compositor carioca estréie publicamente com um recital que incluirá algumas composições que já estavam escritas e que se acham muito mais liga-

\footnotetext{
6- É contemporânea a esta série uma outra, também para piano, que foi denominada Prelúdios do Crepúsculo e que apresenta como movimentos os seguintes títulos: 1-Evocação da Tarde; 2- Idílio; 3- Ocaso; 4Angelus; 5- Pirilampos. Trata-se de uma série igualmente descritiva. Da mesma forma, enquanto as Historietas Maravilhosas só tiveram sua primeira audição em novembro de 1923, os Prelúdios do Crepúsculo só a teriam em abril de 1925 - o que mostra como nestes primeiros anos da década de 20 ainda deveriam conviver os dois estilos do compositor.

7- Lorenzo Fernândez produziria em 1932 mais uma Suíte Infantil para piano, esta intitulada Bonecas (1- A Dançarina Espanhola; 2- A Pastorinha Portuguesa; 3- A camponesa Italiana; 4- A Lenhadora Russa; 5 - A Baianinha das Cocadas). Em 1933 seria a vez de Bazar (1- O Cavaleiro Fantástico; 2- O Pião de Música; 3- O Ferreiro Automático; 4- O Barquinho de Vela; 5- O Trenzinho de Mola). Em 1937 viria a suíte infantil Minhas Férias (1- Madrugada; 2- Manhã na Praia; 3- Caçando Borboletas). E em 1944 virá uma última suíte infantil com Boneca Yayá (1- Yayá Dançando; 2- Yayá Sonhando; 3- Yayá Brincando).
} 


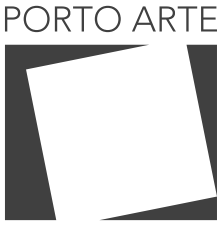

Revista de Artes Visuais v $25 n .44$ Jul/dez 2020 e-ISSN: 2179-8001

das à fase anterior do que ao novo caminho. Dentro deste estilo, destacam-se no recital de estreia um Noturno (1920) e um Arabesco para piano (1921), bem como duas canções (Cisne e Ausência). 0 que ocorre é que este ano está destinado a ser tão ambíguo quanto importante na produção musical de Lorenzo Fernândez: a opção nacionalista foi tomada, mas ainda não houve tempo hábil para a elaboração de um repertório de peso dentro dos novos parâmetros que em breve seriam percorridos.

A ambiguidade do ano de 1922 na trajetória musical de Lorenzo Fernândez - funcionando como uma espécie de misturador de águas das duas fases (a que iria ser abandonada e a que estava prestes a ser assumida de maneira imperiosa) - mostra que a Semana de Arte Moderna, ocorrida em fevereiro daquele ano, não teria sido o único evento importante para que o compositor carioca assumisse mais rapidamente a dupla opção pela modernidade e pelo nacionalismo. Terá contribuído com o seu quinhão de influência a atuação corajosa e decisiva de Luciano Gallet no Instituto Nacional de Música, culminando com o polêmico recital nacionalista em dezembro daquele ano. Basta lembrar que os recitais de Villa-Lobos para o evento modernista de São Paulo ainda tinham trazido muita música impressionista - moderna, sem dúvida, mas não exclusivamente nacionalista. Já os recitais cariocas de Luciano Gallet no final do ano, impondo a presença de Ernesto Nazareth na torre de marfim que era o Instituto Nacional de Música, terminam por escancarar o mundo do Nacionalismo Musical para todos os que o quisessem ver. E um dos que o queriam ver era Lorenzo Fernândez.

0 ano decisivo mesmo será o de 1924. Além de uma série de obras como a Canção Sertaneja e a Elegia para violoncelo e piano, aparece aqui uma obra de especial quilate: o Trio Brasileiro ${ }^{8}$ para piano, violino e violoncelo (1924). Para prosseguir com a metáfora de antes, pode-se dizer que aqui se completava o processo de modulação que conduzira daquela mescla de impressionismo e neo-romantismo até um Nacionalismo Musical mais assumido, e que finalmente Lorenzo Fernândez tinha um caminho muito bem definido à frente ${ }^{9}$.

\section{Lorenzo Fernândez e a afirmação do Nacionalismo Musical}

O Trio Brasileiro, uma obra que já afirma francamente a opção de Lorenzo Fernândez pelo nacionalismo musical, é também uma obra exemplificativa da atrás mencionada prática - típica de Lorenzo Fernândez - de entretecer forma e conteúdo mutuamente. Do ponto de vista da forma, teremos aqui uma estrutura essencialmente cíclica (onde os temas recorrem de maneira transfigurada e os movimentos integram-se através desta recorrência temática). Do ponto de vista do conteúdo, são utilizados temas caracteristicamente nacionais, e muito mais sintonizados com a busca de uma

\footnotetext{
8- Antes deste Trio, Lorenzo Fernândez já tinha escrito um Trio n¹ em 1921, e há também um Idílio Romântico (1924) que também é para violino, violoncelo e piano. Mas é mesmo o Trio Brasileiro que lança as bases de seu nacionalismo musical

9- Já se notou, aliás, que também na Literatura é somente a partir de 1924 que começam a aparecer os grandes manifestos nacionalistas (como o "Pau Brasil" de Oswald de Andrade). Antes desta data, o modernismo literário teria sido muito mais modernista (em oposição ao passadismo) do que nacionalista. É precisamente em 1924 que começa a ser abandonada a ênfase na absorção das conquistas da vanguarda européia em favor de uma ênfase prioritária na necessidade de elaboração de uma cultura nacional.
} 


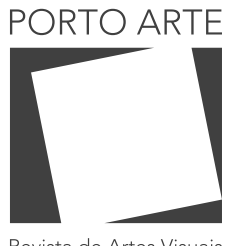

Revista de Artes Visuais

v $25 n .44$

Jul/dez 2020 e-ISSN: 2179-8001

comunicabilidade direta do que com as preocupações musicológicas de coleta de temas folclóricos autênticos. Temas musicalmente comunicativos e forma bem estruturada conspiram, nesta obra, para evitar simultaneamente a banalização e o hermetismo modernista. $O$ biscoito é fino, mas não tanto que não possa ser imediatamente comido pela Massa - e com isto se realiza o delicado acordo entre uma sofisticada lógica formal e a espontaneidade da escrita musical.

Assim ocorre, por exemplo, no primeiro movimento. Trata-se de um Allegro maestoso em 'forma sonata' que contrapõe dois temas caracteristicamente brasileiros, mas da lavra do próprio autor, e que depois de serem expostos, desenvolvidos e reexpostos mais uma vez - como é de se esperar na 'forma sonata' - acabam confluindo para uma surpreendente Coda final baseada na célebre melodia do "Sapo Cururu", tantas vezes utilizada pelos compositores nacionalistas do Brasil. É muito interessante notar, ainda, que através da seção intermediária de 'Desenvolvimento Temático' já começam a se insinuar neste movimento inicial, ainda que de maneira muito fragmentária, certos temas que logo aparecerão nos movimentos posteriores. Com isto vai se configurando precisamente o caráter cíclico deste Trio Brasileiro.

Um destes temas é uma melodia folclórica do Ceará, que já aparece integralmente no Segundo Movimento - um Andante intitulado "Canção" que também devolve algumas reminiscências temáticas oriundas de materiais utilizados no Primeiro Movimento. É assim que vai sendo urdida com habilidade e sofisticação uma integração cíclica entre os vários movimentos: o anterior antecipa fragmentariamente certos materiais temáticos que só serão expostos integralmente no movimento subsequente, e este tanto remete ao movimento anterior através de reminiscências, como já antecipa pequenas sugestões do material temático que surgirá no próximo movimento. Fina arquitetura, embora utilizando materiais bastante assimiláveis pelo ouvinte comum.

Sobrevém depois da Canção um Scherzo (nacionalisticamente intitulado Dança) que apresenta sucessivamente um tema que lembra o populário urbano do Rio de Janeiro e um tema afro-brasileiro, mas que no fim de tudo também é conduzido para uma Coda mais uma vez baseada no "Sapo Cururu". O quarto e último movimento (Allegro Moderato) introduz um tema captado do folclore sertanejo do Mato Grosso pela célebre expedição de Roquete Pinto, da qual se valeram tantos dos nossos compositores nacionalistas - e mais uma vez o tema novo se combina com reminiscências temáticas de todos os movimentos anteriores.

Este Trio Brasileiro já permite entrever muito dos aspectos que reunimos atrás como característicos da música de Lorenzo Fernândez. Parte dos temas utilizados é elaborada à maneira de 'folclore imaginário' (temas criados pelo próprio autor, mas dentro de uma ambientação folclórica bem estudada) - mas de qualquer maneira aparecem três temas recolhidos de material folclórico preexistente: duas intervenções do "Sapo Cururu", uma intervenção transfigurada de um tema folclórico do Ceará, e um tema sertanejo recolhido do Mato-Grosso. As várias regiões do país dialogam em uma mesma canção (embora não polifonicamente, como já vimos ter ocorrido em alguns dos Choros de Villa-Lobos). Terão voz aqui o Rio de Janeiro, o Ceará, o Mato Grosso, a rítmica 


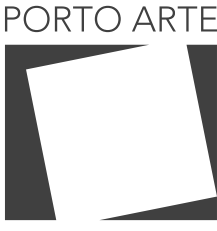

Revista de Artes Visuais

v $25 n .44$

Jul/dez 2020

afro-brasileira e uma cantiga de ninar que aparece em diversas regiões do país - cada coisa a seu tempo, de modo a dotar a música de bastante inteligibilidade musical (que é outra das características de Lorenzo Fernândez). E enformando tudo isto uma estrutura musical muito bem estabelecida, mas que parece ser urdida em perfeito acordo com o conteúdo temático utilizado. Este é o Lorenzo Fernândez definitivo, que daí em diante apenas tenderá a aprimorar os aspectos composicionais que já aparecem germinalmente integrados neste Trio.

O Trio Brasileiro é o grande ponto de partida para outras obras de câmara, como a Suíte para Quinteto de Sopros (1926), para flauta, oboé, clarinete, fagote e trompa. Esta obra, uma das mais executadas e ouvidas de Lorenzo Fernândez, mostra claramente como aqueles elementos que aparecem germinalmente no Trio Brasileiro vão sendo confirmados e aperfeiçoados para constituir uma linguagem camerística que será típica do compositor carioca. Está lá a atenta estruturação musical aliada a um conteúdo produzido à maneira de 'folclore imaginário'. A novidade, talvez, é que Lorenzo Fernândez traz para esta obra também o seu espírito programático, que tantas vezes o levará a produzir música dando asas a uma rica imaginação descritiva que transforma os vários movimentos e episódios de uma composição em cenas pitorescas. No caso, ele utiliza ao lado do nome formal de cada movimento uma designação cênica, e nesta ordem aparecem os quatro movimentos do seu Quinteto: 1 - Pastoral ("Crepúsculo do Sertão"); 2 - Fuga ("Saci-Pererê"); 3 - "Canção da Madrugada"; 4 - Scherzo ("Alegria da Manhã"). Todos os fundamentais interesses estéticos do compositor, inclusive o programatismo dos primeiros tempos, parecem encontrar nesta composição um definitivo ponto de conciliação ${ }^{10}$.

\section{As composições vocais de Lorenzo Fernândez}

Vamos voltar ao decisivo ano de 1924. Ao mesmo tempo em que compunha o Trio Brasileiro, Lorenzo Fernândez abriria naquele mesmo ano um novo espaço para o Nacionalismo Musical através de sua obra vocal. Neste âmbito, a sua escolha de poemas a serem musicados sempre será muito conscienciosa, e aparecerão entre seus parceiros alguns dos maiores nomes do primeiro modernismo: Graça Aranha, Mário de Andrade, Ronald de Carvalho, Manuel Bandeira e Jorge de Lima ${ }^{11}$. A Canção Sertaneja (1924) será a primeira de uma série de outras canções com piano que, além de apresentar temática nacional, serão escritas estritamente em linguagem musical brasileira.

\footnotetext{
10- Na música de câmara para cordas, as duas próximas grandes obras serão o Quarteto n 1 em fá \# menor (1927) e o Quarteto n² em dó menor (1946). O primeiro antecipa a utilização da politonalidade que será tão comum nas obras da última fase de Lorenzo Fernândez. O último é já uma das últimas obras do compositor carioca, portanto bem articulado com obras da última fase como as Primeira e Segunda Sinfonia (1945 e 1946) e a Sonata Breve para piano (1947)

11- Graça Aranha (1868-1931) e Mário de Andrade (1893-1945), como já foi ressaltado, foram intelectuais-chaves para o movimento iniciado pela Semana de 1922. Quanto a Ronald de Carvalho (1893-1935) também ligado ao movimento, teve uma de suas obras mais destacadas com os Epigramas irônicos e sentimentais (1922) que foram musicados por Villa-Lobos para a Semana de Arte Moderna.. Manuel Bandeira também teve o seu poema Os Sapos declamado no mesmo evento, embora não estivesse presente pessoalmente. Jorge de Lima (1893-1953) iniciou a sua atividade poética em 1914 com os XIV Versos Alexandrinos, mas é na década modernista que ele passa a utilizar o verso livre com o livro O Mundo do Menino Impossível (1926), daí seguindo sucessivamente com diversas obras até A Invenção de Orfeu (1952).
} 


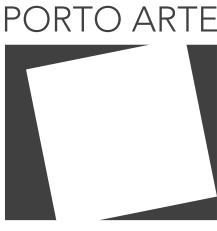

Revista de Artes Visuais v $25 n .44$ $\mathrm{Jul} / \mathrm{dez} 2020$ e-ISSN: 2179-8001

No caso desta canção que consolida definitivamente o seu estilo vocal nacionalista, destaca-se a interessante sugestão de um cavaquinho através da mão esquerda do piano, com um efeito similar ao que será também empregado em Canção do Violeiro (1926) para sugerir uma viola caipira. Macumba (1926), com versos de Murilo Araújo (1894-1980), é uma outra canção bastante característica que busca recuperar o ambiente do ritual afro-brasileiro de mesmo nome.

Mas o grande ponto de chegada do cancioneiro de Lorenzo Fernândez é a famosa Toada prá você (1928), com versos de Mário de Andrade. Esta canção passa por ter inaugurado quase um estilo de composição vocal - logo batizado de "voceísmo" - e que despertaria a composição de canções similares da parte de diversos autores, inclusive 0 Doce nome de você de Francisco Mignone.

A primeira edição de Toada prá Você teria esgotado em uma semana a venda de mil exemplares. Já indicamos o fato de que, nas primeiras décadas do século XX - sobretudo antes da extraordinária difusão que os meios radiofônicos teriam a partir da década de 30 - a partitura de música podia contar com uma saída extraordinária, particularmente porque ela se dirigia a um público que não era necessariamente formado por músicos profissionais. Este vasto público de músicos amadores e domésticos havia crescido notavelmente com a proliferação da Imprensa Musical a partir do período romântico, e perdurou até a primeira década do século XX. Depois disto, com o Rádio e o Disco ele começa a diminuir, já que as famílias de classe média passam a contar com estes outros meios para introduzir um pouco de música em suas vidas cotidianas. Toada prá você ainda pôde contar com este extraordinário mercado de partituras musicais - coroamento de um mundo onde as famílias ainda se reuniam com maior frequência para a prática de saraus de música erudita. Para além de Toada prá você, existem ainda outras canções de Lorenzo Fernândez que merecem destaque, e que quase chegam perto da Toada em termos de popularidade. Uma delas é a célebre Essa Nega Fulô (1934), desenvolvida sobre os famosos versos de Jorge de Lima que inspiraram também outros compositores a lhe encontrarem música. Canção do Mar (1934), da mesma época e sobre versos de Manuel Bandeira, é outra que se destaca pela sutileza de um acompanhamento que busca descrever pianisticamente o movimento das ondas sem cair em clichês desgastados.

De um modo geral, o que se pode dizer do cancioneiro de Lorenzo Fernândez produzido na fase mais radicalmente nacionalista é que ele se aproxima do modelo vocal das Serestas de Villa-Lobos. Quase sempre o compositor cria um ambiente de 'folclore imaginário', e só muito raramente aproveita de modo mais direto motivos folclóricos conhecidos ou recolhidos previamente - situação que ocorre, por exemplo, em Noite de junho (1934), canção sobre versos de Ronald de Carvalho que se baseia em motivo inspirado na canção de roda 0 anel que tu me deste. Com relação às canções da última fase, elas se aventuram em uma melódica a que já não se exige o compromisso nacionalista mais imediato, rendendo obras como Dentro da Noite (1946), ou ainda como o Vesperal (1946) e a Elegia da manhã (1946) - ambas miniaturas sobre dois epigramas de Ronald de Carvalho que já se preocupam mais com o aspecto modernista do que com o aspecto nacionalista. 


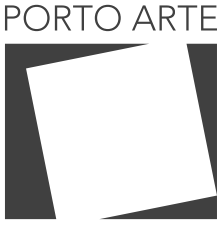

Revista de Artes Visuais

$\vee 25 n .44$

$\mathrm{Jul} / \mathrm{dez} 2020$ e-ISSN: 2179-8001

\section{A produção orquestral}

A produção orquestral de Lorenzo Fernândez também se inicia em 1924, com um Concerto para Piano que logo seria seguido, no ano seguinte, por uma Suíte Sinfônica sobre três temas populares brasileiros (1925). Mas a primeira obra orquestral de peso é o poema sinfônico Imbapara (1926), depois transformado em bailado. Esta obra investe no nacionalismo musical a partir de três direções. Em primeiro lugar através da temática, já que Imbapara é um poema sinfônico ameríndio baseado em um texto do folclorista e historiador Basílio de Magalhães (1874-1957). Em segundo lugar através da sua orquestração, que inclui instrumentos de origem indígena. Por fim através da própria música, que aproveita melodias dos índios parecis do Mato Grosso que haviam sido recolhidas pela expedição de Roquete Pinto. Uma destas melodias é a já célebre Nozani-ná, que foi também utilizada por Villa-Lobos em uma das Canções Típicas Brasileiras (1919) e, mais tarde, no Choros $n^{\circ} 3(1925)^{12}$.

Estabelecendo contato com o mundo ameríndio através da temática, da instrumentação e de seus materiais de base, Imbapara descreve o martírio de um guerreiro índio que, capturado, será vítima de um ritual antropofágico. 0 sucesso deste poema sinfônico foi tanto que logo o compositor carioca seria convidado a compor um outro na mesma linha - o Amaia (1930) - que exploraria agora um enredo envolvendo as sociedades incaicas da época da chegada dos espanhóis à América ${ }^{13}$. 0 sucesso não se repetiu com a mesma intensidade, e acabou sendo o último trabalho orquestral de Lorenzo Fernândez com temática ameríndia.

Sucesso ainda mais definitivo estaria na suíte Reisado do Pastoreio para grande orquestra (1930). O último movimento - o Batuque - é aliás uma das composições mais conhecidas de Lorenzo Fernândez. 0 primeiro movimento é o Reisado propriamente dito, e para entender a sua proposta vale a pena relembrar o que significa esta manifestação folclórica que deu origem à suíte sinfônica do compositor carioca.

O Reisado é uma pantomina folclórica, ao mesmo tempo uma encenação e dança dramática que é muito típica das festas juninas do Nordeste ou das festas natalinas em outras regiões do país. Intermesclando motivações profanas e religiosas, o reisado mais típico do Nordeste acontece através da reunião de um grupo de foliões em um "rancho" que se dispõe a percorrer as vizinhanças cantando e dançando, visitando mais particularmente as residências de pessoas da localidade que se prestam a receber o rancho com alegria e hospitalidade. Estas visitas às residências são chamadas de "embaixadas' e encaminham um roteiro cênico padronizado que admite variações conforme as várias regiões, apresentando como seus personagens mais habituais o Rei, o Mestre, o Contramestre, Mateus e Catarina. A encenação do Reisado é repetida em cada casa que o rancho visita, integrando o próprio dono da casa na sua dramatização.

\footnotetext{
12- A melodia foi recolhida pela Missão Rondom, na primeira metade do século XX, e inserida na coletânea em que Roquete Pinto registrou esse material musical recolhido entre etnias diversas de índios brasileiros (ROQUETE PINTO, 1935).

13- O enredo deste bailado é da lavra do próprio Lorenzo Fernândez, que investe mais uma vez na tragédia sacrificial com ingredientes de heroísmo e amor. Com relação à música, o compositor satura as suas referências melódicas de escalas pentatônicas, o que confere a esta obra uma sonoridade bastante exótica.
} 


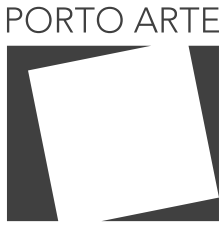

Revista de Artes Visuais

$\vee 25 n .44$

$\mathrm{Jul} / \mathrm{dez} 2020$ e-ISSN: 2179-8001

No Sudeste e Centro do país, o Reisado também pode ser chamado de Folia de Reis, e costuma ocorrer no período natalino. Neste caso gira em torno de personagens bíblicos como os reis magos, mas também pode incorporar figuras folclóricas diversificadas como o Boi, a Arara, o Caipora, o Mestre-sala, e assim por diante. A mesma interação entre visitas a residências, enredo encenado e folguedo público através das ruas acontece também nos Reisados do sul e do centro do país. Em certas regiões, o Reisado incorpora elementos do já descrito Bumba-meu-boi, e neste caso a sua principal característica é a farsa do boi, onde este animal dança, brinca, é morto e por fim ressuscitado. Nesta última versão, é mais legítimo falar em um "Reisado do Pastoreio".

É este ambiente das danças dramáticas brasileiras que Lorenzo Fernândez toma como motivação para a sua suíte sinfônica Reisado do Pastoreio. No caso, têm-se três movimentos de caráter contrastante: o "Reisado", a "Toada", e finalmente o "Batuque". Este último movimento é inspirado nas danças de mesmo nome que, no período coIonial, foram trazidas da Angola e do Congo para o mundo das senzalas brasileiras. o Batuque integra dança, sensualidade e ritual religioso indutor de transe - tudo isto incorporado em uma única e impressionante manifestação do folclore de origem escrava. O Batuque era também um grito de resistência que, transfigurado em ritmo e música, emergia oportunamente do mundo das senzalas nas ocasiões permitidas. Neste caso, o colonizador branco bem sabia que deveria permitir ao negro certos espaços de catarse e manifestação de sua identidade cultural - sob o risco de que, na ausência destes espaços, a população escrava acabasse canalizando suas forças reprimidas em revoltas contra a ordem escravocrata estabelecida. Por isto o Batuque também pode assimilar uma característica de dança guerreira, oculta sob a capa da manifestação ritualística de negros que estão submetidos.

É um pouco deste vigor guerreiro, associado à obstinação da ritualística afro-brasileira, o que Lorenzo Fernândez consegue captar com este movimento sinfônico. $\mathrm{Na}$ suíte composta pelo compositor carioca, este último movimento acabou adquirindo tanta projeção que, com bastante frequência, é apresentado isoladamente no repertório das orquestras sinfônicas. Como o Bolero de Ravel, é uma destas composições que conseguem obter um efeito insuperável a partir de uma máxima economia de elementos. No caso, com um formidável crescendo dinâmico e timbrístico que é habilidosamente estabelecido sobre uma ininterrupta e insistente base rítmica, o Batuque é conduzido a um final verdadeiramente apoteótico. Inserido no enredo maior do Reisado, o Batuque representaria o processo de revivicação do boi, portanto de vitória da Vida sobre a Morte (e, porque não dizer, do escravo oprimido sobre o branco opressor). O movimento sinfônico tem tido sucesso assegurado de público nas constantes apresentações de orquestras que o tomam para repertório.

O outro grande sucesso de Lorenzo Fernândez em gêneros monumentais foi a ópera Malazarte (1931-1933). Estreada em 1941, esta ópera em quatro atos foi baseada em um drama do mesmo nome de autoria de Graça Aranha. Já é então uma obra da última fase - aquela que muitos autores chamam de "nacionalismo essen- 


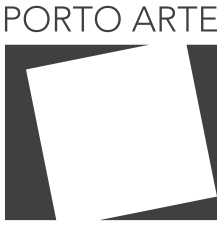

Revista de Artes Visuais

v. 25 n. 44

$\mathrm{Jul} / \mathrm{dez} 2020$ e-ISSN: 2179-8001

cial"14, no sentido de que continua assegurando uma brasilidade intrínseca mas admitindo um maior diálogo com o universalismo musical. Assim mesmo, o primeiro ato de Malazarte encontra espaço para produzir interessantes associações entre os ambientes folclórico e popular, reaparecendo tanto os gêneros oriundos do folclore histórico como as modinhas e batuques, como também as cantilenas nordestinas, as marchinhas e trechos associáveis ao populário chorão. Curiosamente, ocorre que a ópera Malazarte tem sua trama falada e cantada em italiano (uma versão do texto original de Graça Aranha, que era em francês). A sua música, contudo, é a mais brasileira que até então já havia aparecido no gênero ópera.

\section{Composições para piano}

Setor da obra musical de Lorenzo Fernândez que conta com algumas composições de destaque é o da música para piano. Não é um repertório muito extenso, mas apresenta pelo menos seis composições importantes: na fase mais acentuadamente nacionalista, os Três estudos em forma de sonatina (1929), a Valsa Suburbana (1932), as três Suítes Brasileiras (1936, 1938 e 1938); na última fase a Sonata Breve (1947). Marca também a sua posição nesta última fase a Suíte das cinco notas (1942), que se constitui de pequenas peças sobre as notas musicais, sem falar nas várias suítes infantis que já foram mencionadas em nota anterior.

As três suítes brasileiras para piano ocupam uma posição importante não apenas devido ao excelente resultado estético que as conservou definitivamente no repertório pianístico, mas também em razão da sua função didática e de pesquisa folclórica. Elas de certo modo apresentam ao público vários gêneros musicais do folclore brasileiro que são sintetizadas nos nove movimentos que as compõem (cada uma das suítes brasileiras é constituída de três movimentos).

A Suíte Brasileira $n^{\circ} 1$ (1936) apresenta sucessivamente como movimentos uma modinha, uma canção de ninar e uma seresta, denominando-se estes movimentos "Velha Modinha", "Suave Acalanto" e "Saudosa Seresta". O primeiro movimento é tão bem sucedido em sugerir na mão esquerda do piano um acompanhamento de violão, que mais tarde o autor elaborou uma versão para violão solo que foi dedicada a Andres Segóvia (1938).

Já os movimentos da Suíte Brasileira n 2 (1938) são respectivamente o "Ponteio", a "Moda" e o "Cateretê". O que mais se destaca é também o último movimento, o "Cateretê", ressaltando-se que é aqui que este gênero folclórico é empregado pela primeira vez em uma composição de música erudita. 0 Cateretê, aliás, tem uma história particularmente singular na história do sincretismo. Nos tempos recentes, este gênero folclórico aparece como uma dança popular aos pares, com tamancos duros e batidas de palmas, que se dá ao som de violas de cantadores. É uma manifestação rural muito comum em diversas regiões como Paraná, São Paulo, Rio de Janeiro, Minas Gerais, Mato Grosso, Goiás e diversos estados nordestinos. Mas o Cateretê, em perí- 


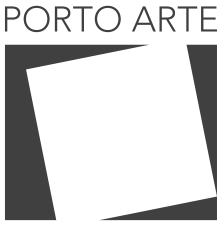

Revista de Artes Visuais

$\vee 25 n .44$

$\mathrm{Jul} / \mathrm{dez} 2020$ e-ISSN: 2179-8001

odo mais recuado, teria tido origem como uma dança religiosa dos índios, já desde a época de chegada dos portugueses. O Padre José de Anchieta teria composto por esta época alguns cateretês, para finalidades de catequese, e com isto teria dado a partida em um importante processo de sincretismo ao qual se juntaria mais tarde a vertente negra através da rítmica afro-brasileira. Neste ponto, o Cateretê começa a sincretizar também o profano e o mágico-religioso. Depois viria a contribuição das violas sertanejas para este gênero, e a coreografia da dança se adaptou muito eficazmente ao ritmo das violas. Existe mesmo uma expressão comum entre os dançarinos do cateretê que diz que estes devem "pisar nas cordas da viola" (o que significa dizer que o ritmo dos pés deve coincidir com o do violão). Para realizar esta integração afinada entre viola e dança, o cateretê conta habitualmente com dois violeiros-cantadores (o mestre e o contramestre), além de cinco ou mais pares de dançarinos. É esta dança admiravelmente sincrética que Lorenzo Fernândez transpõe para o último quadro de sua Suíte Brasileira $\mathrm{n}^{\circ} 2$. Procura captar o seu intrincado rítmico de batidas de palmas, sapateados e acompanhamento de viola e adapta-Ihe uma forma bem transparente, ternária, como, aliás, ocorre com boa parte dos movimentos das suítes brasileiras. Se expressa aqui o já mencionado cuidado do compositor carioca em entretecer forma e conteúdo de maneira intencionalmente equilibrada, sem deixar que um suprima o outro.

A Suíte Brasileira n 3 (1938) apresenta como movimentos a "Toada", a "Seresta" e o "Jongo". Este último vem a ser uma das composições pianísticas mais importantes de Lorenzo Fernândez. É interessante notar que, no seu Jongo, o compositor opta pela extinção gráfica da barra de compassos - embora seja patente que a célula rítmica do ostinato termine por estabelecer um ritmo compassado que bem poderia se ajustar a uma quadratura métrica. 0 programa dinâmico e expressivo do Jongo é similar ao que havia sido empregado no já analisado Batuque para orquestra: trata-se de ir adensando a sonoridade, em um gradual crescendo, até atingir um final apoteótico.

De um modo geral pode-se perceber, nos vários movimentos pertencentes às Suítes Brasileiras, aquela tão bem elaborada urdidura de forma e conteúdo que se tornou uma marca registrada de Lorenzo Fernândez. Com muita frequência, aparecem nestes movimentos as formas mais típicas do neoclassicismo musical. Mostra-se bastante comum a forma ternária ABA' (uma seção inicial é contrastada por uma seção que sugere um ambiente musical diferente, e depois se verifica o retorno a um ambiente similar àquele em que se iniciara a música). Assim ocorre com a "Saudosa Seresta" da Suíte $\mathrm{n}^{\circ}$ 1, com a "Moda" e o "Cateretê" da Suíte $n^{\circ} 2$, ou com a "Toada" da Suíte $n^{\circ}$ 3. Mas também ocorre a 'forma estrófica' (uma seção-padrão que se repete algumas vezes com ou sem modificações) sempre que a modalidade popular a ser sugerida assim o pede. É o caso do "Ponteio" da Suíte $\mathrm{n}^{\circ} 2$, peça lenta e expressiva em uma tonalidade menor e compasso binário (2 / 4) que procura sugerir no acompanhamento o toque de viola típico do Brasil Rural. Neste caso, a forma estrófica apresenta-se em três seções (A,A,A'). 


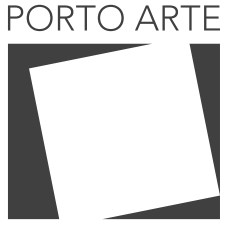

Revista de Artes Visuais

$\vee 25 n .44$

$\mathrm{Jul} / \mathrm{dez} 2020$ e-ISSN: 2179-8001

\section{Música de Câmara}

Além de sua produção pianística, relativamente pequena, mas de importância essencial, Lorenzo Fernândez ainda dedicou-se a gêneros compactos da música de câmara. Já abordamos o Trio Brasileiro e o Quinteto de Sopros, que são peças de maior significado por funcionarem como um ponto de partida para o próprio estilo nacionalista do compositor carioca. Mas também não devem ser esquecidas as Invenções Seresteiras (1944). Lorenzo Fernândez compôs ao todo cinco invenções: Três Invenções Seresteiras para clarinete e fagote (1944) e Duas Invenções Seresteiras para flauta, clarinete e fagote (1944). Para entender estas invenções para sopros, é preciso recuperar o espírito deste gênero musical que é já antigo na História da Música.

O gênero 'Invenção' remete ao período Barroco. De lá nos chegam os modelos que foram celebrizados por Johann Sebastian Bach (1685-1750) para as Invenções a duas Vozes (1723) e para as Invenções a três vozes (1723) - sendo que estas últimas teriam sido chamadas por Bach de "Sinfonias", mas com um sentido radicalmente distinto de 'sinfonia' enquanto gênero sinfônico (sinfonia, no caso, significaria "soar bem", implicando na ideia de acordo musical através da harmonia e do contraponto) ${ }^{15}$. As 15 Invenções a duas vozes e as 15 Invenções a três vozes são pequenas peças para cravo, que depois foram assimiladas pelo repertório pianístico de maneira similar ao que aconteceu com as fugas deste mesmo compositor. São peças que até hoje fazem parte da formação inicial do pianista erudito, e Bach na verdade as teria escrito com explícitos propósitos didáticos - mais especificamente para contribuir para a formação de seu filho Wilhelm Fridmann, que como os demais filhos de Bach também se tornaria um bom músico.

As Invenções de Bach são pequenas composições polifônicas Conforme já foi visto, a 'Polifonia' é aquele método de apresentação musical no qual várias vozes distintas, com a mesma importância e todas conduzindo melodias, soam simultaneamente (ao contrário da 'Homofonia', onde apenas uma voz aguda conduz a melodia principal e as demais fornecem fundamentalmente uma base de sustentação harmônica). Quando existe um compromisso temático entre as diversas vozes, e uma vai como que respondendo a outra (mais ou menos como se tivéssemos uma conversa musical), temos a chamada 'Polifonia Imitativa', que, embora tenha começado a surgir no final do Renascimento, tornou-se muito característica de alguns compositores barrocos como Bach e Haendel. Na Polifonia Imitativa, a cada instante uma das vozes pode estar conduzindo o tema (também chamado de "sujeito" na Fuga, ou de motivo temático nas demais formas e gêneros que também se caracterizam pela polifonia imitativa). Não existe nestes casos uma voz que seja mais importante que as outras, e elas alternam-se sucessivamente na condução dos motivos temáticos enquanto as

\footnotetext{
15- Bach começou a compor as Invenções em 1720, mas só em 1723 as revisou e acondicionou-as em um álbum intitulado Invenções e Sinfonias, cujo prefácio deixa muito claro os seus propósitos didáticos: "Guia Honesto através do qual se mostra aos amantes do teclado e em particular, aos que desejam aprender, um modo simples não só de tocar corretamente em duas vozes, mas também à medida que progridem, de tratar três vozes obligato com perfeição e ao mesmo tempo, de adquirir boas idéias e elaborá-las adequadamente, e, sobretudo, aprender um estilo cantabile de execução e, simultaneamente, adquirir o gosto antecipado pela arte da composição" (Subtítulo do Livro de Invenções e Sinfonias).
} 


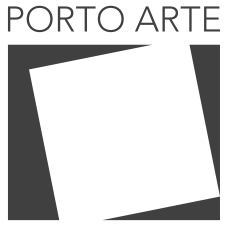

Revista de Artes Visuais

$\vee 25 n .44$

$\mathrm{Jul} / \mathrm{dez} 2020$ e-ISSN: 2179-8001

outras, que naquele momento não estão com motivos temáticos mais importantes a seu cargo, apenas tecem um "contraponto". Contraponto é precisamente a prática de conduzir simultaneamente várias vozes musicais.

A Fuga - uma das formas musicais que lidam com o contraponto - é uma forma polifônica mais ou menos rigorosa, onde um tema (o "sujeito") começa a circular pelas diversas vozes com mudanças de altura e de tonalidade (no caso, as fugas podem ser a 2, 3, 4, 5 vozes, e assim por diante). Mas o que diferencia a Fuga da Invenção é que esta última lida de maneira um pouco mais livre com a polifonia imitativa. A Fuga tem uma certa sequência de apresentação do tema em tonalidades específicas (logo no início, por exemplo, o tema deve ser apresentado por uma voz no 'tom principal' da música, e ser imediatamente respondido por uma outra voz no 'tom da dominante'). Já a Invenção não segue obrigatoriamente esquemas deste tipo. Ela lida mais livremente com a imitação do motivo temático. Este pode ser imitado a qualquer hora e na altura que o compositor desejar. Pode ser imitado com modulação a outra tonalidade ou dentro do mesmo tom (cada hora o compositor faz de um jeito, de acordo com a sonoridade que melhor lhe apraz). 0 tema também pode ser imitado de trás para diante, de cima para baixo, ou mesmo apenas ritmicamente. A Invenção produz um trabalho de polifonia imitativa bastante livre.

No período moderno, a Invenção conservou a sua natureza contrapontística. Nem sempre manteve o aspecto de polifonia imitativa, embora isto também possa ocorrer. É possível, neste caso, conservar as duas ou três vozes em uma relação polifônica mais independente (não-imitativa, no sentido rigoroso do termo). É com estes dois tipos de Invenção que Lorenzo Fernândez quis dialogar quando compôs as suas Invenções Seresteiras. Do mesmo modo que Villa-Lobos dialogou com a forma 'Fuga' em alguns dos movimentos de suas Bachianas, Lorenzo Fernândez dialoga com o gênero 'Invenção' nestas pequenas peças para duos ou trios de sopros. 0 essencial nestas composições é o 'contraponto' que se estabelece entre as vozes musicais, cada qual representada por um instrumento distinto. Nas três primeiras Invenções Seresteiras ele experimenta a pouco usual combinação de clarinete e fagote em duo, e nas duas últimas invenções Ihes acrescenta uma flauta, de modo a trabalhar com um trio de sopros ${ }^{16}$.

Também é muito interessante notar que Lorenzo Fernândez explora estas já pouco usuais combinações camerísticas procurando obter timbres internos diferenciados para cada uma das Invenções Seresteiras. Na primeira das invenções para clarinete e fagote, por exemplo, ele trata o fagote como se este estivesse fazendo um baixo melódico como aqueles que eram tão típicos do violão na música dos chorões do início do século, erguendo sobre esta base para o cantabile do clarinete. Na segunda o tratamento é experimental no que se refere aos mais audaciosos intervalos melódicos (saltos grandes entre uma nota e outra) e à invenção rítmica - de modo que tanto o clarinete como o fagote soam com uma escritura bastante moderna. A terceira obtém uma timbrística bastante tradicional, dialogando mais diretamente com a música barroca (de maneira

16- No Choros n² (1923), Villa-Lobos experimentara um duo de flauta e clarinete; e nas Bachianas Brasileiras $n^{\circ} 6$ (1938) irá trabalhar com duo de flauta e fagote. A combinação de clarinete e fagote, trabalhada por Lorenzo Fernândez, complementa estas possibilidades de combinações. 


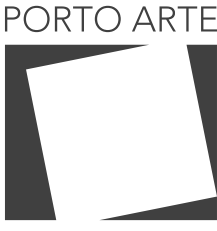

Revista de Artes Visuais

$\vee 25 n .44$

$\mathrm{Jul} / \mathrm{dez} 2020$ e-ISSN: 2179-8001

similar ao que já faziam os chorões nas suas peças mais polifônicas). Neste caso, a terceira das invenções para clarinete e fagote é aquela que dialoga mais com o modelo de polifonia imitativa das invenções de Bach. As demais soam mais modernas nas suas relações de contraponto, desobrigando-se dos modelos mais barrocos de imitação.

As cinco Invenções Seresteiras, de qualquer maneira, constituem cinco pequenas obras-primas do contraponto. Ao lado do Quarteto $\mathrm{n}^{\circ} 2$ em Dó menor (1946) encerram em excelente nível a pequena produção camerística de Lorenzo Fernândez. Mas esta última obra já representa o mesmo estilo terminal que aparece nas duas Sinfonias dando mostras de que, se tivesse tido mais tempo, o compositor tenderia a transcender o folclorismo que durante muito tempo fora uma referência importante em sua produção musical ${ }^{17}$. Vejamos então este último período de sua vida, quando Lorenzo Fernândez dá mostras de pretender se dedicar com especial afinco aos gêneros orquestrais. Aos seus primeiros trabalhos sinfônicos, ele já havia acrescentado nos anos anteriores um Concerto para Violino e Orquestra (1941). Mas agora finalmente ele se achava pronto a enfrentar um desafio maior. Iria escrever as suas duas sinfonias - a Sinfonia $\mathrm{n}^{\circ} 1$ em 1945 e a Sinfonia $\mathrm{n}^{\circ} 2$ em 1946.

\section{A última fase composicional de Lorenzo Fernândez e as sinfonias}

A Sinfonia $n^{\circ} 1$ (1945) é um marco importante, porque nela o compositor afasta-se de qualquer intenção nacionalista, mostrando-se mais disposto a explorar decididamente o universalismo musical. Já vimos que esta data corresponde precisamente ao início do pós-guerra, quando o Brasil se abre para novas possibilidades de intercâmbio cultural, correspondendo também ao encerramento do Estado Novo de Getúlio Vargas, este que estimulara uma política cultural de tipo populista para atender a objetivos políticos específicos. O fim de Guerra e o fim de Vargas contextualizam a passagem para um estilo mais universalista em muitos dos compositores que haviam sido mais radicalmente nacionalistas.

Na sua Sinfonia $n^{\circ} 1$, Lorenzo Fernândez utiliza formas neoclássicas bem tradicionais. 0 primeiro movimento é uma típica 'Forma-Sonata' - estrutura musical que já discutimos tomando para exemplo as Sonatas e Sinfonias de Camargo Guarnieri. 0 compositor lida também, em alguns trechos, com a politonalidade - experiência que será retomada mais sistematicamente na sua última obra para piano, a Sonata Breve (1947). O trecho central do Desenvolvimento da 'Forma-Sonata' expressa pela Sinfonia $\mathrm{n}^{\circ} 1$ é território absoluto da politonalidade. Será também uma Forma-Sonata o que ouviremos no quarto movimento da Sinfonia $n^{\circ} 1$, mas bastante modificada e chegando à novidade de utilizar três temas (ao invés de dois) e de entrelaçá-los no final da música.

\footnotetext{
17- Particularmente interessante é o Segundo Movimento do Quarteto $n^{\circ} 2$, onde o autor deliberada e sistematicamente transgride os parâmetros mais tradicionais da Harmonia - partindo a princípio de falsas relações cromáticas e chegando por fim a um conflito de tonalidades que, no trecho terminal do movimento já se expressa em uma completa autonomia tonal de cada uma das vozes (cada instrumento, a esta altura já se expressa em uma tonalidade distinta). É a politonalidade trabalhada metodicamente, brotando grad ualmente de um ambiente tonal sem que o ouvinte perceba quando foi que isto precisamente aconteceu Obra inovadora do ponto de vista dos procedimentos harmônicos
} 


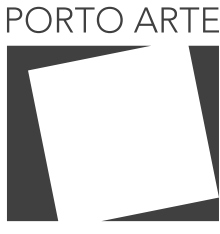

Revista de Artes Visuais

v $25 n .44$

Jul/dez 2020 e-ISSN: 2179-8001

Ao contrário da Sinfonia $\mathrm{n}^{\circ} 1$, que é "música pura" concebida neoclassicamente, a Sinfonia $n^{\circ} 2$ (1946-1947) é "programática", inspirando-se no texto do poema épico 0 Caçador de Esmeraldas de Olavo Bilac. A chamada "sinfonia de programa" ou "sinfonia programática" tem afinidades com o gênero Poema Sinfônico, já esclarecido anteriormente. Às vezes, este dois gêneros podem até se confundir, mas habitualmente eles comportam distinções algo sutis. O Poema Sinfônico é frequentemente narrativo - isto é, neste caso ele "narra" através de música exclusivamente orquestral uma história de menores ou maiores proporções, tal como ocorre com o Amazonas de Villa-Lobos ou com o Imbapara de Lorenzo Fernândez (que também podem ser transformados em Bailados - gênero que pode ser visto como uma espécie de poema sinfônico coreografado). Mas alguns poemas sinfônicos ao invés de "narrarem" fazem outra coisa: eles "descrevem" (uma cena, um estado de espírito, e assim por diante). São os 'poemas sinfônicos descritivos' que se confundem um pouco com as 'sinfonias programáticas' (a possibilidade de "descrever musicalmente" é, por assim dizer, a fronteira difusa entre os dois gêneros).

Entrementes, a Sinfonia Programática volta a marcar uma distância em relação ao Poema Sinfônico quando ela apenas se inspira em um texto ou poema, ou mesmo em um simples tema ou situação. As cinco primeiras sinfonias de Villa-Lobos (as da fase impressionista) são Sinfonias Programáticas: elas se inspiram respectivamente no Imprevisto, na Ascensão, na Guerra, na Vitória e na Paz. Ou seja, inspiram-se em "situações". A primeira Sinfonia Programática da História da Música, embora na época não tenha sido classificada com este nome em vista do ineditismo desta ideia, foi a Sinfonia $n^{\circ} 6$ de Beethoven (1808) - também chamada de "Sinfonia Pastoral" - que procurou descrever nos seus cinco movimentos um piquenique que acaba se transformando em tempestade e que termina com um "canto de pastores", aproveitando neste ínterim para descrever algumas cenas da Natureza e a alegria contagiante de uma festa na aldeia. Depois, já no período romântico, Hector Berlioz escreveu uma Sinfonia Fantástica (1830) que divagava sobre a sua própria vida. E logo Franz Liszt (que passa também por ser o inventor do Poema Sinfônico) escreveria uma Sinfonia Fausto (1855) e uma Sinfonia Dante (1856). Estas sinfonias programáticas são baseadas respectivamente no famoso poema de Goethe (17491832), que conta a história do homem que vendeu a alma ao Diabo, e na "Divina Comédia" - poema que contém uma terrível e minuciosa descrição do Inferno conforme a imaginação do poeta medieval Dante Alighieri (1265-1321).

Vamos voltar agora (ou avançar) ao século XX, para este Brasil que lutava por afirmação cultural na música erudita e que deu origem aos seus próprios poemas sinfônicos e sinfonias programáticas - muitos deles baseados em temas nacionais ou em textos de poetas nacionais. Já vimos que Lorenzo Fernândez explorara o gênero Poema Sinfônico com Imbapara, narrando uma história ameríndia que no seu enredo mistura primitivismo, amor e rituais de sacrifício humano. Em seguida, o poema sinfônico Amaia explorou um enredo incaico de autoria do próprio compositor. Com a sua Sinfonia $n^{\circ} 2$, o compositor carioca irá se inspirar no poema 0 Caçador de Esmeraldas, do poeta parnasiano Olavo Bilac (este poema épico, aliás, também foi tomado como base para um dos bailados de Francisco Mignone). 


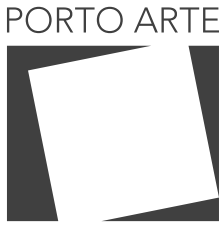

Revista de Artes Visuais

v. 25 ก. 44

$\mathrm{Jul} / \mathrm{dez} 2020$ e-ISSN: 2179-8001

O que faz da Sinfonia $\mathrm{n}^{\circ} 2$ de Lorenzo Fernândez uma Sinfonia Programática, e não um Poema Sinfônico, é o fato de que o compositor carioca não segue propriamente nesta obra orquestral o roteiro do poema de Olavo Bilac. Na verdade, o que ele faz é tomar quatro trechos deste grande poema (ou mais propriamente quatro grupos de "tercetos", que são estrofes de três versos) e utilizá-los como epígrafes inspiradoras para cada um dos quatro movimentos de sua Sinfonia. Ele apenas se inspira no poema de Olavo Bilac - não o segue descritivamente - e para ilustrar a sua inspiração registra acima de cada um dos movimentos a estrofe inspiradora. Apenas para dar um exemplo, o terceiro movimento da Sinfonia, que é um andamento lento chamado "Lamentoso", possui como epígrafe a seguinte estrofe melancólica:

\section{"... E a Natureza assiste,}

Na mesma solidão e na mesma hora triste,

À agonia do herói e à agonia da tarde"

Esta epígrafe corresponde a um desalentador movimento lento que se inicia com uma triste melodia nos violinos sobre uma nota insistente nas trompas e uma marcação pianíssima no tam-tam, daí crescendo para uma sonoridade grandiosa com toda a orquestra e depois retornando ao ambiente de desespero e desalento. 0 quarto e último movimento, por exemplo, toma para epígrafe três versos que intermesclam solidão e perseverança triunfalista, e procura exprimir através de pura música orquestral este combinado ambíguo de sentimentos. Eis aí, plenamente realizada, a sinfonia programática de Lorenzo Fernândez.

A última obra orquestral de Lorenzo Fernândez, e na verdade a sua última composição, corresponde às Variações Sinfônicas para piano e Orquestra (1948). Ele morreria pouco mais de um mês depois de concluir esta obra, que é sua experiência monumental com a forma 'Tema e Variações'. No caso, são quinze variações habilmente elaboradas sobre um tema folclórico - apropriado "canto de cisne" para um compositor que tanto se dedicara à música brasileira.

O Tema e Variações é a última grande forma musical que convém registrar. É uma forma antiga, que vem desde a época do Renascimento, quando os alaudistas espanhóis do século XVI gostavam de tomar uma canção popular conhecida e compor "diferenças" sobre esta canção - isto é, sucessivas reapresentações variadas ou modificadas deste tema básico. A forma musical atravessou o período barroco de maneira mais elaborada (as Variações Goldberg de Bach são um exemplo), e atingiu o período clássico já sob o nome de 'Tema e Variações'. Haydn, Mozart e Beethoven foram mestres nesta forma musical. Mais tarde alguns compositores românticos continuaram a compor variações (Schumann, Liszt, Brahms), e a forma musical finalmente atingiria o século $X X$.

A ideia do Tema e Variações é bastante simples. 0 compositor apresenta um tema - que pode ser uma canção popular conhecida, uma melodia folclórica, uma cantiga de ninar, ou mesmo um tema simples produzido pelo próprio compositor - e depois come- 


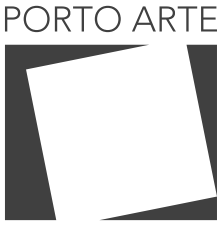

Revista de Artes Visuais v $25 n .44$ Jul/dez 2020 e-ISSN: 2179-8001

ça a reapresentá-lo sucessivamente, mas sempre com variações que modificam o tema em algum aspecto mais ou menos importante. Ele pode, por exemplo, intercalar mais notas musicais entre as notas básicas de uma melodia simples (quanto mais simples uma melodia for, melhor para ser tomada como Tema e Variações, já que a função do compositor será a de dar uma feição cada vez mais complexa a este tema na medida em que for avançando nas suas diversas variações). Outro tipo de variação possível é a rítmica: o compositor pode conservar mais ou menos as notas da melodia, mas modificar os seus valores de duração. 0 mesmo também pode ser feito com relação ao aspecto harmônico: neste caso, o compositor conserva a melodia mas modifica a sua base harmônica criando novos acordes ou alterando os acordes originais. Existe ainda, em alguns casos, a possibilidade de fazer exatamente o contrário: conservar uma determinada harmonia de base à qual o ouvido já tenha associado o tema desde o início e, surpreendentemente, fazer desaparecer a melodia inicial substituindo-a por uma outra).

Há inúmeras alternativas de variações à disposição do compositor. Existe por exemplo a variação de modo, que consiste em apresentar em 'modo menor' um tema que originalmente era em 'modo maior'. Pode-se também fazer a variação de andamento (apresentar com andamento mais lento um tema allegro, ou vice-versa), e ainda a variação de compasso (o tema que era em compasso 3 / 4 passa a ser apresentado em compasso 2 / 4). Pode-se, em uma outra variação, dar um tratamento polifônico ao tema (isto é, fazer com que ele dialogue com ele mesmo em duas vozes). Se a composição for para orquestra ou conjunto incluindo instrumentos diferentes, pode-se explorar a mudança de timbres como variação. E é possível ainda variar o acompanhamento (um acompanhamento de acordes em bloco na mão esquerda do piano dá lugar a um acompanhamento sob a forma de arpejos).

Na verdade, existem inúmeras possibilidades de variar uma melodia, e mais possibilidades ainda de combinar dois ou três tipos de variação como os que atrás exemplificamos. É possível, assim, combinar a 'variação de andamento' com a 'mudança de modo', de maneira a transformar um tema alegre em um trecho mais melancólico. E é possível ainda imaginar novos padrões de variação, independentes dos que foram dados como exemplos. O Tema e Variações é uma das formas musicais que requer maior habilidade técnica do compositor.

É com esta forma musical que Lorenzo Fernândez encerra a sua bela carreira de compositor. A obra é para piano e orquestra - isto é, o piano adquire uma função solista bastante importante, como se tivéssemos um concerto para piano e orquestra. Mas todos os instrumentos da orquestra são muito bem explorados, em uma obra-prima de orquestração. 0 tema escolhido para ser variado é neste caso uma melodia extraída do folclore brasileiro que é conhecida como "Morocututú". Os vários processos de variação que listamos acima, e muitos outros mais, são empregados por Lorenzo Fernândez. Depois de apresentar o tema no naipe de cordas da orquestra, ele explora na 1a Variação uma mudança de acompanhamento, introduzindo o piano e também o clarinete. $\mathrm{Na}$ 13a Variação, por exemplo, ele dá um tratamento polifônico ao tema, que naquele trecho quase se transforma em uma pequenina fuga. A última variação termina de maneira grandiosa (com frequência a 'Variação Terminal' de um Tema e Variações é mais 


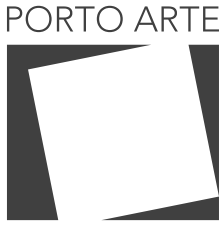

Revista de Artes Visuais

$\vee 25 n .44$ $\mathrm{Jul} / \mathrm{dez} 2020$ e-ISSN: 2179-8001

desenvolvida do que as outras, ocupando mais compassos do que as precedentes que como regra possuem a mesma extensão do tema apresentado inicialmente).

Cerca de um mês depois de concluir esta obra, Lorenzo Fernândez iria falecer. Ironicamente, na noite que precedeu a sua morte ele havia regido triunfalmente um concerto com peças suas, com entusiástica acolhida do público. Estava no auge de sua atividade como compositor, como educador, e como organizador musical - também dirigindo o Conservatório Brasileiro de Música, do qual fora um dos fundadores. Muitos acreditavam que, sendo ele dez anos mais novo do que Villa-Lobos, seria o seu sucessor natural. Mas invertendo as expectativas, a morte de Villa-Lobos só viria acontecer onze anos depois da de Lorenzo Fernândez. Falecendo com a idade de apenas cinquenta anos, não se pode saber que extraordinárias contribuições este compositor ainda teria a oferecer à criação musical.

\section{Referências das composições de Lorenzo Fernândez}

Amaia (bailado, 1930).

Arabesco (piano, 1921).

Ausência (canto e piano, 1922).

Batuque (da suíte sinfônica Reisado do Pastoreio, 1930).

Bazar (suíte infantil para piano, 1933).

Bonecas (suíte infantil para piano, 1932).

Boneca Yayá (suíte infantil para piano, 1944).

Canção do Mar (canto e piano, 1934).

Canção Sertaneja (canto e piano, 1924).

Canção do Violeiro (canto e piano, 1926).

Cateretê (da Suíte Brasileira ${ }^{\circ} 2$ para piano, 1938).

Concerto para Violino e Orquestra (1941).

Cisnes (canto e piano, 1921) Concerto para piano (1925). Dentro da noite (canto e piano, 1946).

Elegia (violoncelo e piano, 1924).

Elegia da manhã (canto e piano, 1946).

Essa Nega Fulô (canto e piano, 1934).

Historietas Maravilhosas (suíte infantil para piano, 1922).

Idílio romântico (piano, violino e violoncelo; 1924).

Imbapara (poema sinfônico / bailado, 1926).

Invenções Seresteiras, 3 (clarinete e fagote, 1944).

Invenções Seresteiras, 2 (flauta, clarinete e fagote, 1944).

Jongo (da Suíte Brasileira ${ }^{\circ} 3$ para piano, 1938).

Macumba (canto e piano, 1926).

Malazarte (ópera, 1931-1933).

Mãos frias. (canto e piano, 1922).

Minhas Férias (suíte infantil para piano, 1934).

Miragem (piano, 1919). 


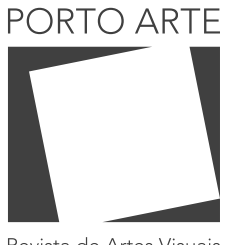

v. 25 n. 44 Jul/dez 2020 e-ISSN: 2179-8001
Noite de junho (canto e piano, 1934).

Noturno (piano, 1920).

Ponteio (da Suíte Brasileira $\mathrm{n}^{\circ} 2$ para piano, 1938).

Prelúdios do crepúsculo (suíte para piano).

Quarteto $n^{\circ} 1$ em fá \# m. (dois violinos, viola, e violoncelo, 1927).

Quarteto $\mathrm{n}^{\circ} 2$ em dó menor (2 violinos, viola, e celo, 1946).

Quinteto de sopros (flauta, oboé, clarinete, fagote e trompa; 1926).

Reisado do Pastoreio (orquestra, 1930).

Saudade (canto e piano, sd).

Sinfonia $\mathrm{n}^{\circ} 1$ (1945).

Sinfonia $\mathrm{n}^{\circ} 2$ (1946).

Sonata Breve (piano, 1947).

Suítes Brasileiras (piano, 1936).

Suíte Brasileira $\mathrm{n}^{\circ} 1$ (suíte para piano, 1936).

Suíte Brasileira $n^{\circ} 2$ (suíte para piano, 1938).

Suíte Brasileira $\mathrm{n}^{\circ} 3$ (suíte para piano, 1938).

Suíte das cinco notas (suíte para piano, 1942).

Suíte para quinteto de instrumentos de sopro (ver Quinteto de Sopros).

Suíte sobre temas populares brasileiros (1926).

Toada para Você (canto e piano, 1928).

Três estudos em forma de sonatina (estudos para piano, 1929).

Trio $\mathrm{n}^{\circ} 1$ (piano, violino e violoncelo; 1924).

Trio Brasileiro (piano, violino e violoncelo; 1924).

Valsa Suburbana (piano, 1890).

Variações sinfônicas (piano e orquestra, 1948).

Velha modinha (da Suíte Brasileira $n^{\circ} 3$ para piano, 1938).

Vesperal (canto e piano, 1946).

\section{REFERÊNCIAS}

ANDRADE, Mário de. Ensaio sobre a música brasileira. São Paulo: Vila Rica, 1972 [original: 1928].

ANDRADE, Mário de. Lorenzo Fernández. Crônica publicada no Diário de São Paulo em 26 de janeiro de 1934. In: CASTAGNA, Paulo (org.). Música e Jornalismo. São Paulo: Hucitec, 1993. ANDRADE, Mario de. Música, doce música. São Paulo: Livraria Martins Fontes, 1934. BARTÓK, Béla. Escritos sobre Música Popular. Madrid: Siglo XXI, 1979.

CANDÉ, Roland de. História Universal da Música, São Paulo: Martins Fontes, 1994, v.2. CASTAGNA, Paulo (org.). Música e Jornalismo. São Paulo: Hucitec, 1993.

CONTIER, Arnaldo. Brasil novo, música, nação e modernidade: os anos 20 e 30 . São Paulo: FFLCH-USP (Tese de Livre Docência), 1988.

CORREA, Sergio Nepomuceno. Lorenzo Fernández: catálogo geral. Rio de Janeiro: Rio Arte, 1992.

EGG, André. Considerações sobre o Nacionalismo Musical no Brasil: Camargo Guar- 


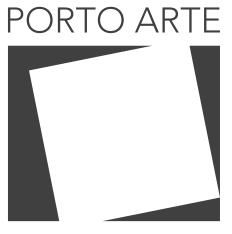

Revista de Artes Visuais

v. 25 ก. 44 Jul/dez 2020 e-ISSN: 2179-8001 nieri e Frnacisco Mignone. Revista Científica/FAP (Curitiba), vol..2, p.143-156, jan./dez. 2007.

EGG, André. O debate no campo do nacionalismo musical no Brasil dos anos 1940 e 1950: o compositor Guerra Peixe. Curitiba: UFPR (Dissertação de Mestrado), 2004.

GALLET, Luciano. Estudos de Folclore. Rio de Janeiro: Carlos Wehrs \& Cia, 1934.

GANDELMAN, Salomea. Compositores Brasileiros - obras para piano (1950-1988). Rio de Janeiro: FUNARTE / Relume - Dumará, 1997.

GRIFFITHS, Paul. A música moderna: uma história concisa e ilustrada de Debussy a Boulez. Rio de Janeiro: Zahar, 1998.

KATER, Carlos. Música Viva e Koellreutter. São Paulo: Musa, 2001.

LORENZO FERNÂNDEZ. Villa-Lobos. Boletim Latino Americano de Música. a.5, n6, abril de 1946.

MARIZ, Vasco. Figuras da Música Brasileira Contemporânea. Porto: 1948.

MARIZ, Vasco. História da Música no Brasil. Rio de Janeiro: Nova Fronteira, 2000.

MOREUX, Serguei. Béla Bartók, Richard-Masse, 1954.

NEVES, José Maria. Música contemporânea brasileira. Rio de Janeiro: Recordi, 1981.

ROQUETE PINTO. Rondônia. São Paulo: CEN, 1935.

VILLA-LOBOS, Heitor. Lorenzo Fernândez. Boletim Latino Americano de Música. a.6, $\mathrm{n}^{\circ} 6$, abril de 1946.

WISNIK, José Miguel. O coro dos contrários: a música em torno da Semana de 22. São Paulo: Duas Cidades, 1977. 


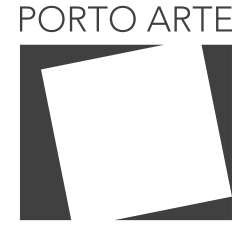

Revista de Artes Visuais

v. $25 n .44$ Jul/dez 2020 e-ISSN: 2179-8001

\section{José D'Assunção Barros}

Professor-Associado da Universidade Federal do Rio de Janeiro. Professor Permanente do Programa de Pós-Graduação em História Comparada da Universidade Federal do Rio de Janeiro. Doutor em História pela Universidade Federal Fluminense.

Texto submetido em: 01/07/2020

Texto aceito em: 15/10/2020

Texto publicado em: 20/12/2020 